https://doi.org/10.52058/2786-4952 -2022-1(6)-45-52

Боднар Тетяна Олександрівна аспірант кафедри педагогіки та інноваційної освіти, Національний університет «Львівська політехніка», вул. Степана Бандери, 12, Львів, 79000, тел.: (097) 589-63-50, https://orcid.org/0000-0002-1497-5955

\title{
ФОРМУВАННЯ ІКТ-КОМПЕТЕНТНОСТІ ПЕДАГОГІВ В СИСТЕМІ ВИЩОЇ ОСВІТИ УКРАЇНИ
}

Анотація. Запропоновано до розгляду проблема ІКТ-компетентності вітчизняних педагогів в закладах вищої освіти України. У зв'язку із швидким розвитком інформаційно-комунікаційних технологій та їх впливу в освітній напрям, перед українськими освітянами постала низка викликів, зокрема поступове знецінення якості, втрата довіри до української освіти серед сучасних українських студентів. Представники покоління «Y» та «Z», які постійно перебувають серед гаджетів, технологічних зручностей та в безкінечному інформаційному потоці, вимагають від освітньої індустрії нових урізноманітнених способів забезпечення знань. Навчальний процес не повинен бути стандартним, таким як ми звикли його уявляти, примітивний чи складно доступний. Для звичних до життя з гаджетом в руці, зараз надається перевага присутності технологій всюди, зокрема і в освітньому процесі, тому вони ретельно шукають для себе ті освітні пропозиції, які не будуть обтяжувати, а навпаки спрощувати студентські життя водночас здобуваючи релевантні знання. Мета даної статті дослідити поняття ІКТ-компетентності педагогів на основі тверджень вітчизняних науковців. Одним із завдань дослідження висвітлити сучасні практики використання ІКТ-засобів в навчальному процесі в закладах вищої освіти України з метою розуміння, які засоби інформаційнокомунікативних технологій практикують сучасні викладачі в умовах змішаного та дистанційного навчання. Зокрема було проаналізовано досвід залучення інформаційних технологій в навчальному процесі іноземними закладами вищої освіти. На основі порівняння вітчизняних та іноземних практик запропонувати можливі рішення проблеми пасивного розвитку процесу інформатизації в системі університетської освіти України.

Ключові слова: інформаційно-комунікативні технології, IКTкомпетенція, цифрова грамотність, ЗВО, віртуальні середовища.

Bodnar Tetiana Oleksandrivna Postgraduate student of the Department of Pedagogy and Innovative Education of the Lviv Polytechnic National University, Stepana Bandery St., 12, Lviv, 79000, tel.: (097) 589-63-50, https://orcid.org/00000002-1497-5955 
Журнал«Герстективита інновації наукиљ

(Серія«Гедагогіка», Серія «Геихологія», Серія «Медицина»

№(6) 2022

\title{
FORMATION OF TEACHERS ICT COMPETENCE IN THE SYSTEM OF UKRAINIAN HIGHER EDUCATION
}

\begin{abstract}
The problem of ICT competence of domestic teachers in higher education institutions of Ukraine is proposed for consideration. Due to the rapid development of information and communication technologies and their influence in the educational field, Ukrainian educators faced a number of challenges, in particular, gradual devaluation of quality, loss of trust in Ukrainian education among modern Ukrainian students. Representatives of the generation «Y» and «Z», who are constantly among gadgets, technological amenities and in the infinite information flow, require from the educational industry new diverse ways of providing knowledge. The learning process should not be standard, such as we used to imagine it, primitive or difficult to access. For those accustomed to living with a gadget in hand, the presence of technology is now preferred everywhere, in particular in the educational process, so they carefully look for those educational offers that will not burden, but rather simplify student life while gaining relevant knowledge. The purpose of this article is to investigate the concept of ICT competence of teachers based on the statements of domestic scientists. One of the tasks of the research is to highlight modern practices of using ICT tools in the educational process in higher education institutions of Ukraine in order to understand what means of information and communication technologies are practiced by modern teachers in conditions of blended and distance learning. In particular, the experience of attracting information technologies in the educational process by foreign institutions of higher education was analyzed. On the basis of comparison of domestic and foreign practices, offer possible solutions to resolve the problem of passive development of the informatization process in the university education system of Ukraine.
\end{abstract}

Keywords: information and communication technologies, ICT competence, digital literacy, higher education institutions, virtual environments.

Постановка проблеми. Інформаційна доба формує для сучасного суспільства нові умови, сценарії розвитку суспільних сфер життя і залучення інформаційно-комунікативних технологій в ті чи інші сфери. Нинішній інформатизований світ вимагає від суспільства нових знань, вмінь, рішень зокрема, це стосується й освітньої сфери. Сучасна система освіти потребує від майбутніх спеціалістів оновлених знань, якісних підходів до діяльності та перегляду власних вже набутих компетентностей 3 метою розуміння того наскільки якісно виконується фахівцем робота та їх актуальності. На основі стрімкого розвитку та активного використання інформаційно-комунікативних технологій було сформовано нову професійну компетентність - цифрову або ІКТ-компетентність, яка передбачає здатність та вміння правильно, логічно застосовувати інформаційні технології в процесі організації навчання. Цифрова компетентність забезпечує можливості швидко приймати рішення, формувати якісні навчальні матеріали, сприяти залученню студентів до 
навчального процесу навіть не виходячи 3 дому, так як ІКТ-можливості покликані сприяти спрощенню суспільного життя. Тому, до теперішніх практикуючих педагогів також зросли вимоги та запити на вдосконалення своїх компетенцій, де першочерговим $є$ підвищення рівня власної цифрової грамотності.

Аналіз останніх досліджень і публікацій. Проблемі ІКТ-компетентності та залученню інформаційно-комунікативних технологій було присвячено чимало праць та досліджень вітчизняними, зарубіжними науковцями, зокрема Р. Гуревич, А. Гуржій, М. Жалдак, Н. Морзе, О. Спірін, П. Беспалов, А. Слізаров, О. Шилова, які звернули увагу на сутність i структуру IКТ-компетентності та цифрової культури майбутніх педагогів [1; 2]. Використанню інформаційно-комунікативних технологій у вищій освіті присвятили свої роботи В. Бикова, О. Глазунова, М. Шишкіна [3]. Під час дослідження формуванню цифрових компетентностей науковцями доволі часто прослідковуються такі поняття як цифрова компетентність, цифрова/медіа грамотність.

Мета статті. Дослідити поняття IКТ-компетентності та виявити проблему розвитку цифрової грамотності серед українських педагогічних фахівців.

Виклад основного матеріалу. На сьогоднішній день концепція компетентнісного підходу в освітній сфері все більше набуває ключового значення. Виокремлення ІКТ-компетентності як окремої складової професійної компетентності викладача зумовлене стрімким поширенням та впровадженням інформаційних технологій в освітні процеси. Аналізуючи поняття ІКТ-компетентності в низці наукових публікацій можна отримати різноманітні трактування. До прикладу, П.Беспалов пояснює IКТ-компетентність як мотивацію до належного засвоєння знань та здатості до вирішення будь-яких завдань 3 допомогою технологій та володінням прийомів критичного мислення [4]. А. Слізаров під ІКТ-компетентністю пояснює комплекс знань, досвіду у використанні IKT [5]. О. Шилова розуміє IКТ-компетентність як можливість вирішувати професійні, навчальні та життєві обставини за допомоги інформаційних технологій. М. Жалдак та Н. Морзе передбачають вміння орієнтуватись в інформаційному просторі, аналізувати, фільтрувати та систематизовувати відібрану інформацію в глобальній мережі та здатність правильно нею управляти згідно 3 конкретними потребами [1; 2]. Скворцова С. описує IКТ-компетентність як готовність особистості до педагогічної діяльності; до ефективного розв'язання стандартних і проблемних ситуацій у професійній діяльності теоретично та практично [6]. Спірін О. визначає IКТ-компетентність як здатність застосовувати технології в навчанні для опрацювання інформації задля задоволення індивідуальної чи суспільних потреб щодо формування загальних та/або професійних компетентностей [7].

За для інтеграції з міжнародним освітнім простором, сьогодні набуває популярності поняття «цифрової компетентності», наявність якої у 
педагогічного спеціаліста передбачає вміння застосовувати цифрові технології у професійній діяльності, в конкретному випадку в педагогічній. Європейським Парламентом та Радою ЄС в 2006 році цифрова компетентність названа однією 3 ключових компетентностей для навчання впродовж життя. Існує велика кількість різних трактувань поняття цифрової компетентності [8]. Прохорова С. у своєму дослідженні про цифрову компетентність педагога трактує як вміння викладача ефективно використовувати інформаційнокомунікативні технології для професійного педагогічного розвитку. До складових елементів цифрової компетентності входять зокрема додаткові знання, вміння, здатності серед яких технічні навички роботи 3 технологіями, здатність коректно використовувати їх у навчальному процесі, та здатність планувати, аналізувати та керувати освітнім процесом за допомогою IКТінструментів. Педагог має вміти критично оцінювати ресурси та бути добре ознайомленим 3 соціальними та етичними аспектами використання технологій [9]. Дж. Крумсвік вважає, що цифрова компетентність викладача це майстерність, яка застосовується у професійній діяльності [10]. Відбір матеріалів, при цьому відбувається 3 урахуванням специфіки навчальної дисципліни, особливостей студентів, відповідної теми заняття. Скотт С. пояснює цифрову компетентність як вміння критично підходити до використання цифрових ресурсів та інформаційних технологій [11]. Науковець виокремлює такі складові цифрової компетентності: інформаційна і медіа грамотність; онлайн комунікація; технічний та споживацький компоненти. На основі грунтовного аналізу різних проектів та ініціатив А. Феррарі цифрову компетентність формулює як комплекс знань, навичок, які необхідні для використання IКТ та цифрових медіа для виконання завдань; розв'язання проблем; керування інформацією; співпраці; спілкування; створення і поширення коректного контенту [12]. Цифрова компетентність майбутніх педагогічних фахівців $є$ важливою складовою при здійсненні професійної діяльності в умовах інформатизації освіти України. У 2016 році Кабінетом Міністрів України з метою інтеграції у світові процеси було презентовано проект «Цифровий порядок денний України 2020» («Digital Agenda for Ukraine 2020») [13].

Отже, на основі аналізу наукових думок можна зробити висновки, що на сучасному етапі розвитку інформатизації, інформаційна грамотність для українського педагога є вкрай важливою, адже нові пандемічні умови життя завдали своєрідного удару по українській освіті. В умовах онлайн та змішаного навчання студенти потребують нових якісних підходів до процесу організації забезпечення знань від українських педагогів щоб нинішній непростий період для всіх людей жодним чином не вплинув на якість їхньої освіти та після отримання якої студенти б могли стати конкурентоздатними учасниками як українського ринку праці, так і міжнародного.

3 огляду на інтенсивний розвиток інформаційно-комунікаційних технологій та їх впливу на освітню сферу, досвід залучення IКТ-засобів в 
процесі підготовки майбутніх фахівців в закладах вищої освіти України потребує ще багато до опрацювань та якісної реалізації на практиці. На сьогоднішній день, практично в кожному закладі вищої освіти можемо спостерігати практику використання таких технологій як - MS Teams, Zoom, PowerPoint, MS Excel, MS Word, MS Database, Skype, Google Meet, Google Classroom, Moodle, кастомізовані освітні продукти окремих закладів вищої освіти, на кшталт університетських віртуальних середовищ або ж сховищ, де фіксуються дані про публікації.

До порівняння які залучаються та створюються ІКТ-інструменти іноземними педагогами для якісної організації навчання та різносторонньої забезпеченості навчальних матеріалів. Як приклад, в Массачусетському технологічному інституті було створено проект відкритих ресурсів «Open Educational Resources», де викладачі розміщують матеріали, які є доступними в Інтернеті, опубліковані з наданням права подальшого використання [14]. Тим же інститутом спільно з його працівниками було розроблено проект «Open Course Ware», де у відкритому доступі можна знайти будь-який матеріал з усіх курсів проведених інститутом [15]. Схожі проекти були створені освітянами Сльського університету (Open Yale Courses), Державного Каліфорнійського університету (MERLOT) та Техаського Університету Райса (Connexions). Яскравим прикладом технологічних новацій в освіті можна відзначити платформу Piazza, що виступає в ролі інтерактивної навчальної позааудиторної взаємодії. Платформа є абсолютно безкоштовною, простою у використанні і швидкою в налаштуванні для викладачів, що призначена ефективно управляти створеним на платформі Piazza класом. Студенти можуть задати питання і спільно редагувати відповіді на ці питання. Викладачі можуть також відповісти на запитання або підтримати відповіді студентів і редагувати ïx, або видаляти будь-який розміщений зміст. Piazza призначена для імітації реального обговорення навчальних в аудиторії. Використання платформи Piazza у процесі навчання створює умови для реалізації таких методів навчання, як навчання у групах, метод проектів, метод різнорівневого навчання, де студенти виступають у ролі викладачів-консультантів, оскільки бесіди в Piazza можна продовжувати і після закінчення занять в аудиторіях. Під час використання платформи у процесі навчання, можна створити діаграму розвитку конкретного класу на основі діаграми-статистики скільки студентів брало участь в обговореннях та в який період обговорення було досягнуто піку активності студентів [16]. Цікавий приклад спрощення управління навчальними курсами в межах університету $\epsilon$ розробка від Массачусетського технологічного інституту - Система управління навчанням Stellar. Система Stellar надає студентам всі відомості про курси, які вони вивчають, у тому числі оголошення, анонси навчальних програм та календарі курсу, контактні дані викладачів, журнал оцінок. На сайті Stellar викладачі використовують велику кількість програм, у тому числі Web-додатки, для закріплення основних понять, які були представлені в аудиторії. Метою 
Журнал«Герспективитаіновації наукиљ

(Серія «Гедагогіка», Серія«ГЕихологія», Серія«Медицина»

№1(6) 2022

розробки Stellar - зробити доступними навчальні відомості з кожного курсу, що пропонується в Массачусетському технологічному інституті; надавати можливість користувачам створювати інтуїтивно зрозумілий i багатофункціональний Web-сайт для класу або проекту; пропонувати надійне онлайн управління і публікувати навчальні матеріали; автоматизувати трудомісткі адміністративні задачі; забезпечити взаємодію між користувачами шляхом інтеграції вікі; публікувати матеріали досліджень і опитувань тощо [17].

Існує чимало прикладів того, що іноземні заклади вищої освіти, іноземні педагоги давно перетнули межу залучення базових програм з пакету MS Office та інших продуктів, що пропонують в Microsoft для організації навчання. Його використання можна прирівняти як до звичайного зошита, нотатника та іншого. Зараз зусилля тамтешніх педагогів спрямовані не лише на вдосконалення якості забезпечення знань сучасному студенту, а й на спрощення їх отримання. Представники американських, європейських 3ВО вважають, що немає потреби зосереджувати всю увагу на бюрократичних процесах, заповнень значної кількості таблиць, звітностей, а є необхідність прискорити та спростити процес забезпечення знань та їх оцінювання. Створення мобільних та веб-платформ для проведення лекцій, практичних в режимі реального часу, формування освітніх середовищ тому яскраві приклади.

Висновки. Отже, проаналізувавши поняття ІКТ-компетентності та проблему іï розвитку серед вітчизняних педагогів в системі вищої освіти України можна зробити наступні підсумки - в сучасних умовах інформатизації, розвиток ІКТ-компетентності $\epsilon$ обов'язковою вимогою для кожного педагогічного фахівця незалежно від типу освітнього закладу. Розвиток технологій та автоматизація процесів «поглинають» суспільні сфери надто швидко, тому тут $є$ лише два сценарії розвитку, або йти «за течією» та вдосконалювати власні вміння та знання, або залишатись осторонь і віддати можливість автоматизації всіх можливих процесів, що є на разі утопічним сценарієм для України. Щоб залишити за собою авторитет якісної освіти та конкурентоспроможних ЗВО на міжнародному рівні, українським педагогічним спеціалістам не слід боятися йти на експерименти в навчанні, створювати нові способи, методики подачі знань сучасним студентам i намагатись відходити від старих заангажованих технік передачі знань. Зрозуміло, що недостатньо лише амбітних ідей та експериментів для формування нової цифрової педагогіки, оскільки створити щось нове потребує низку зусиль, технічного обладнання, відповідного фінансування. Однак, якщо довести на практиці, що нові методи працюють і доволі якісно демонструючи відповідні студентські показники по завершенню ЗВО, є потреба реалізовувати нові креативні ідеї, не зупинятись експериментувати і в перспективі $є$ всі шанси стати на рівні 3 провідними європейськими та американськими закладами вищої освіти. 


\section{Лimepamypa:}

1. Модель системи соціально-професійних компетентностей вчителя інформатики. Науковий часопис Національного педагогічного університету імені М. П. Драгоманова / М.І. Жалдак, Ю.С. Рамський, М.В. Рафальська, 2009. - С. 3-10.

2. Морзе Н. В. Інформатична компетентність учнів може бути вищою від компетентності тих, хто їх навчає? (за матеріалами моніторингового дослідження 3 інформатичних компетентностей випускників в Україні) / Н.В. Морзе. 2010. - С. 3-8.

3. Биков В. Цифрова гуманістична педагогіка відкритої освіти. Теорія і практика управління соціальними системами / Биков В., Лещенко М., 2016. - С. 115-130.

4. Беспалов П.В. Компьютерная компетентность в контексте личностно ориентированного обучения / П.В.Беспалов. 2003. - С. 41-45.

5. Елизаров А. А. Базовая ИКТ компетенция как основа Интернет-образования учителя. Конференция RELARN-2004. [Електронний ресурс] / А.А.Елизаров. - Режим доступу: http://www.relarn.ru/conf/conf2004/section3/3_11.html.

6. Скворцова С. Професійна компетентність учителя початкових класів. Початкова освіта / С. Скворцова // Методичний порадник. - 2011. - С. 9-12.

7. Спірін О. М. Інформаційно-комунікаційні та інформатичні компетентності як компоненти системи професійно-спеціалізованих компетентностей вчителя інформатики. Інформаційні технології і засоби навчання / О.М.Спірін / - 2009. - С. 1-11.

8. Recommendation of the European Parliament and of the Council of 18 December 2006 on key competences for lifelong learning. (2006/962/EC) // Official Journal of the European Union, 30.12.2006. - L 394/10-394/18 EN.

9. Прохорова С. М. Поняття цифрової компетентності вчителя іноземної мови у світовому освітньому просторі. / С.М. Прохорова // Вісник Житомирського державного університету імені Івана Франка. Педагогічні науки. - 2015. - С. 113-116.

10. Krumsvik, R. Situated learning and digital competence. Education and Information Technology. 4 (13). pp. 279-290.

11. Scott, C. The Futures of Learning 3: What kind of pedagogies for the 21st century? UNESCO Education Research and Foresight, Paris. [ERF Working Papers Series, no. 15] / [Електронний ресурс] / C. Scott. - Режим доступу : http://unesdoc.unesco.org/images/0024/002431/243126e.pdf).

12. Ferrari, A. Digital Competence in Practice: An Analysis of Frameworks. Luxemburg: IPTSJRC. 2011 / [Електронний ресурс] / A.Ferrari. - Режим доступу: http://ftp.jrc.es/EURdoc/ JRC68116.pdf.

13. Цифрова адженда України 2020. Концептуальні засади (версія 1.0). - [Елетронний peсурс]. - Режим доступу: https://issuu.com/mineconomdev/docs/digital_agenda_ukraine-v2_1_

14. Open Educational Resources. MIT Libraries. 2021. - [Електронний ресурс]. - Режим доступу: https://libguides.mit.edu/oer

15. MIT OpenCourseWare. 2021. - [Електронний ресурс]. - Режим доступу: https://ocw.mit.edu/index.htm

16. Piazza. The incredibly easy, incredibly engaging Q\&A platform. 2018. - [Електронний pecypc]. - Режим доступу: https://piazza.com/product/overview

17. MIT Course Management System Stellar. 2021. - [Електронний ресурс]. - Режим доступу: https://wikis.mit.edu/confluence/display/SUG2/Home

\section{References:}

1. Zhaldak M. I., Ramskyi Yu. S., Rafalska M. V. (2009). Model systemy sotsialnoprofesiinykh kompetentnostei vchytelia informatyky. [Model of the system of socio-professional competencies of a computer science teacher]. Naukovyi chasopys Natsionalnoho pedahohichnoho universytetu imeni M. P. Drahomanova. Seriia 2. Kompiuterno-oriientovani systemy navchannia. № 7. [in Ukrainian]. 
2. Morze N. V. (2010). Informatychna kompetentnist uchniv mozhe buty vyshchoiu vid kompetentnosti tykh, khto yikh navchaie? [Can students' computer competence be higher than the competence of those who teach them?]. (Za materialamy monitorynhovoho doslidzhennia $\mathrm{z}$ informatychnykh kompetentnostei vypusknykiv v Ukraini) [in Ukrainian].

3. Bykov V., Leshchenko M. (2016). Tsyfrova humanistychna pedahohika vidkrytoi osvity. Teoriia i praktyka upravlinnia sotsialnymy systemamy. [Digital humanistic pedagogy of open education. Theory and practice of social systems management]. [in Ukrainian].

4. Bespalov P.V. (2003). Kompiuternaia kompetentnost v kontekste lychnostno oryentyrovannoho obuchenyia. [Computer competence in the context of student-centered learning]. Pedahohyka. [in Russian].

5. Elyzarov A. A. (2004). Bazovaia ICT kompetentsyia kak osnova Internet-obrazovanyia uchytelia. [Basic ICT competence as the basis of online teacher education]. Konferentsyia RELARN-2004. URL: http://www.relarn.ru/conf/conf2004/section3 /3_11.html. [in Russian].

6. Skvortsova S. (2011). Profesiina kompetentnist uchytelia pochatkovykh klasiv. [Professional competence of primary school teachers]. Pochatkova osvita. Metodychnyi poradnyk. Vypusk 8 (56). №32 (608). [in Ukrainian].

7. Spirin O. M. (2009). Informatsiino-komunikatsiini ta informatychni kompetentnosti yak komponenty systemy profesiino-spetsializovanykh kompetentnostei vchytelia informatyky. [Information-communication and information competencies as components of the system of professionally-specialized competencies of a computer science teacher]. Informatsiini tekhnolohii $\mathrm{i}$ zasoby navchannia [in Ukrainian].

8. Recommendation of the European Parliament and of the Council of 18 December 2006 on key competences for lifelong learning. (2006/962/EC) // Official Journal of the European Union, 30.12.2006. - L 394/10-394/18 EN

9. Prokhorova S. M. (2015). Poniattia tsyfrovoi kompetentnosti vchytelia inozemnoi movy u svitovomu osvitnomu prostori. [The concept of digital competence of a foreign language teacher in the world educational space]. Visnyk Zhytomyrskoho derzhavnoho universytetu imeni Ivana Franka. Pedahohichni nauky. Vyp. 4. [in Ukrainian].

10. Krumsvik, R. (2008). Situated learning and digital competence. Education and Information Technology.

11. Scott, C. (2015). The Futures of Learning 3: What kind of pedagogies for the 21st century? UNESCO Education Research and Foresight, Paris. [ERF Working Papers Series, no. 15]. URL: http://unesdoc.unesco.org/images/0024/002431/243126e.pdf).

12. Ferrari, A. (2011). Digital Competence in Practice: An Analysis of Frameworks. Luxemburg: IPTS-JRC. URL: http://ftp.jrc.es/EURdoc/JRC68116.pdf.

13. Tsyfrova adzhenda Ukrainy 2020. Kontseptualni zasady (versiia 1.0). [Digital Agenda of Ukraine 2020. Conceptual principles (version 1.0)]. URL: https://issuu.com/mineconomdev/docs/digital_agenda_ukraine-v2__1_

14. Open Educational Resources. MIT Libraries (2021). URL: https://libguides.mit.edu/oer

15. MIT OpenCourseWare (2021). URL: https://ocw.mit.edu/index.htm

16. Piazza. The incredibly easy, incredibly engaging Q\&A platform (2018). URL: https://piazza.com/product/overview

17. MIT Course Management System. Stellar (2021). URL: https://wikis.mit.edu/confluence/display/SUG2/Home 